\title{
Technical Measures to Prevent and Mitigate the Consequences of Arson in School Buildings
}

\author{
NILS JOHANSSON \& PATRICK VAN HEES \\ Department of Fire Safety Engineering and Systems Safety \\ Lund University, P.O. Box 118, SE-221 00 Lund, Sweden, Telephone: +46 462227360 \\ MARGARET SIMONSON MCNAMEE, PETRA ANDERSSON, ROBERT JANSSON \& MICHAEL \\ STRÖMGREN. \\ SP Fire Technology, Borås, Sweden.
}

\begin{abstract}
Fires in school buildings caused by arson are a major problem in Sweden and in particular are the costs of these fires disproportionately high compared to the costs of fires in buildings in general. The Swedish Research Board initiated a multidisciplinary project in order to reduce the number and consequences of arson fires in schools. Both technical and social aspects have been dealt within this project. In this paper an overview of the findings of the sub-project related to technical issues are presented. The goal and purpose of it has been to evaluate technical systems and engineering solutions to prevent and reduce the consequences of arson in school buildings. As part of this has a number of issues been considered including: identification of typical fire scenarios and design fires, an inventory of available technical systems and solutions, small- and real-scale experiments and an extensive cost-benefit analysis of a selection of technical systems.
\end{abstract}

KEYWORDS: arson, detection, suppression, fire growth, cost-benefit

\section{INTRODUCTION}

Arson in buildings is a problem for society and is associated with high costs. In Sweden arson is especially problematic in school buildings (including both schools and pre-schools) and the problem has been escalating during the last decade. Today around half of the 500-600 school fires annually are started deliberately [1]. These fires rarely lead to any fatalities or injuries and are therefore not considered to constitute a life safety problem. However, the annual cost of arson fires in school buildings is roughly 50 million euros in Sweden, which constitutes $10 \%$ of the total cost of building fires in the country. School buildings may be the most severely affected, but arson is also common in other types of buildings, e.g. about 400 arson fires occur every year in apartment buildings.

The Swedish Fire Research Board (Brandforsk) launched a multidisciplinary umbrella project in 2008 as a consequence of the escalating number of arson fires and increased cost of these fires. The overall objective of the project was to, in the long-term, reduce arson in Sweden. In an exploratory study conducted by SP Fire Technology [2] it was concluded that the problem must be addressed broadly using a multidisciplinary approach and a number of research areas were identified as important. In 2009 the full research program was launched with some short orientational projects, followed up by the start of several 3-year projects in 2010. A total of six different Swedish universities and research institute have been involved in different projects. In this paper the findings from the project related to technical issues are presented. Results from studies of social issues are available in research reports from other participants in the umbrella project $[3,4]$

There are several different types of technical systems that can be used to mitigate the consequences of arson but no systematic study of the function, efficiency and economics of installing these systems has been conducted until now. Some of the findings in this project have been presented previously [5-8] but the aim of this paper is to give an overview and compilation of the results.

\section{CHARACTERISTICS OF ARSON IN SCHOOL BUILDINGS}

In order to be able to evaluate the efficiency and economics of technical systems that could be used to prevent and mitigate the consequences of arson it was necessary to start with a study of the characteristics 
of arson in school buildings. Therefore, a case study [5] and literature survey of available design fire data [8] was conducted. A summary of these studies is given in this section.

Almost 60 arson fires in Swedish school buildings were included in the case study [5]. The case study consisted of a Meta analysis of fire investigation reports, supplied by the Swedish Civil Contingencies Agency (MSB). The following five aspects of the fires were studied and evaluated in the case study:

- Ignition source/first material ignited

- Room/place of origin

- Spread of fire

- Time to detection and fire service notification

- $\quad$ Building properties (such as age, type of construction)

The study resulted in the identification of a number of technical deficiencies in the current fire protection of school buildings. Lack of detection systems and automatic alarm systems, bad constructions and insufficient or malfunctioning fire compartments were some of the deficiencies. Some typical fire scenarios were also identified as important for further studies of technical systems and a survey of design fire data [8] was initiated in order further investigate these scenarios and to gather information on fire growth and ignition sources for these scenarios. The literature survey led to four scenarios being presented and described (see Table 1).

Table 1: Summary of literature survey and experimental setup

\begin{tabular}{|l|l|l|l|}
\hline No & Description & Max HRR (kW) & Material \\
\hline 1 & Exterior fire & $100-500^{\mathrm{a}}$ & Wastes \\
\hline 2 & $\begin{array}{l}\text { Small vehicle } \\
\text { against façade }\end{array}$ & $1000-1300^{\mathrm{a}}$ & Motorcycle with plastic hull. \\
\hline 3 & $\begin{array}{l}\text { Flammable liquid } \\
\text { Molotov cocktail }\end{array}$ & $\begin{array}{l}50-800^{\mathrm{a}} \\
300-1300^{\mathrm{a}}\end{array}$ & $\begin{array}{l}\text { Gasoline on combustible floor } \\
\text { Gasoline }\end{array}$ \\
\hline 4 & Fireworks & $20-100^{\mathrm{b}}$ & Fireworks \\
\hline
\end{tabular}
a literature data
experimentally determined within study

The purpose of identifying these typical fires was to use them in an inventory and evaluation of possible measures to prevent and mitigate the consequences of arson. Thus, the next step of the project was to identify suitable passive and active fire protection systems with regard to the typical initial fires in Table 1.

The first scenario involves a fire outdoors next to the school building façade. The fire is started in some rubbish that might be soaked in a flammable liquid. The second scenario also occurs outdoors but the first object ignited has a larger potential heat release rate (HRR), e.g. a small car or moped. In both these exterior fire scenarios the fire develops and flames extend along the façade. If the building is a one-story building, which is a common construction in Swedish school buildings, the fire can spread to the attic and further on to the rest of the building through ventilated eaves (see Figure 1).

The third scenario involves flammable liquids being thrown into the school, typically outside school hours. In some cases Molotov cocktails have been used which can create a fast burning fire. Usually a fire detection system or intrusion detector activates which can alert the rescue service and there can be time to prevent the fire from extending to the entire building. In the fourth scenario fireworks were identified as the ignition source. Fireworks can be fired into a school through ventilation openings or smashed windows. Comprehensive information was found in the literature survey with regard to the first three scenarios. However, only limited information was found regarding fireworks as an ignition source. Thus, an experimental test series was initiated and experiments were performed to gather more information concerning the potential thermal attack from fireworks. 


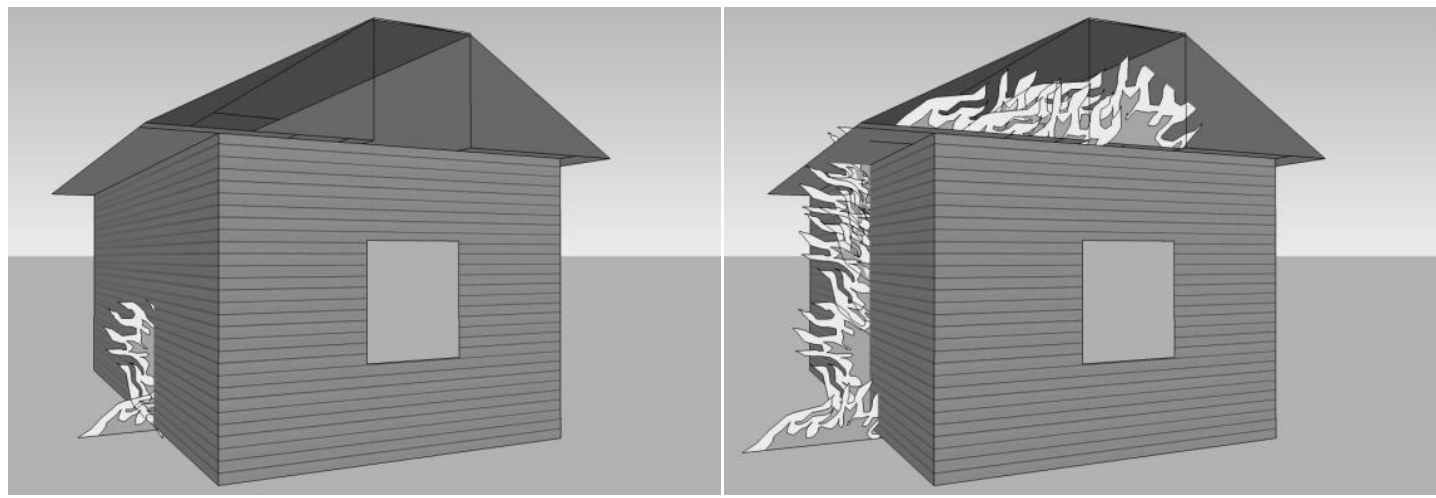

Figure 1: A typical scenario that in many cases will cause a large damage to the building. A small exterior fire that is lit and can grow and spread into the attic because no detection system is present.

\section{Heat Release Rate of Fireworks}

As no literature data was available on heat release rates from fireworks this had to be measured. This is not a straightforward process as fireworks provide their own oxygen, which introduces an error if the oxygen consumption method [9] is used to measure the heat release rate. Moreover, the time span of combustion of fireworks is quick in relation to measurement methodology used for oxygen consumption calorimetry, which makes the measurements unreliable. Therefore, it was decided to use type $\mathrm{K}$ thermocouples at a number of locations and heights around the fireworks $[8,10]$. In addition was a plate thermometer placed under the fireworks, $0.27 \mathrm{~m}$ from the thrust zone of the fireworks, in order to estimate the fireworks thermal attack and corresponding HRR. Temperature readings from the plate thermometer can be seen in Figure 2. Based on these measurements the total incident radiation to the plate was calculated. Comparative tests performed in a Cone Calorimeter with similar heat irradiance and exposure time suggest that upholstered furniture, wooden material and particle boards may be ignited by the type of firework studied. The measurement data did not give an immediate answer to the HRR. Rather, an estimate was made by assuming that the heat originated from a point source radiating over a sphere. A full description of the results from the experiments is given in a separate publication [7].

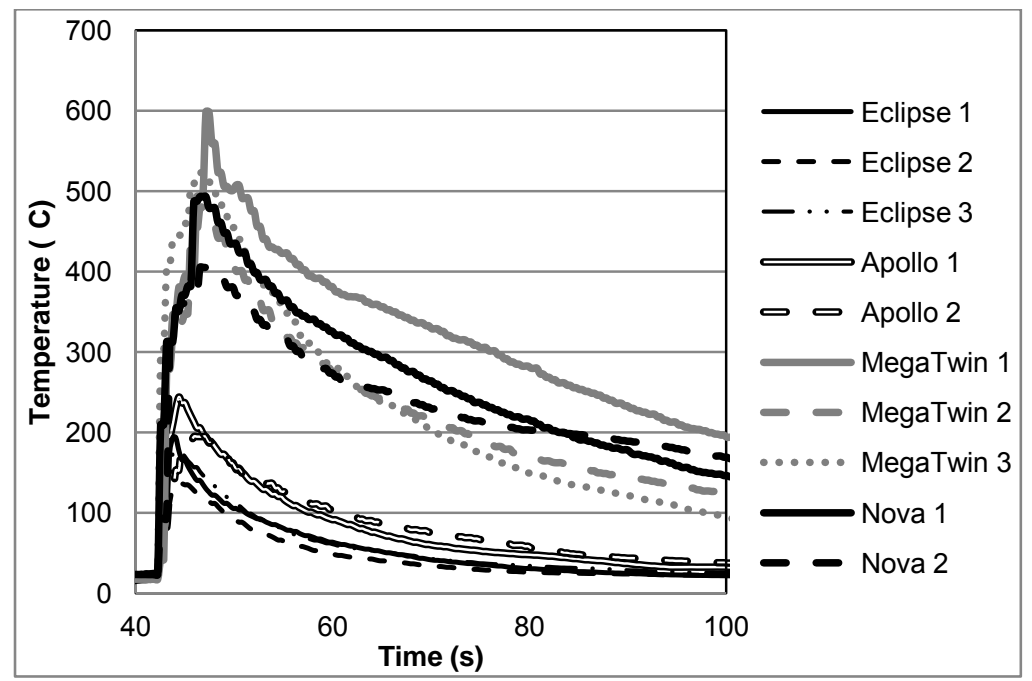

Figure 2: Temperature readings from the plate thermometer in the experiments with fireworks [7].

The experiments gave a ballpark figure for the thermal impact. One uncertainty in the estimate is that in some cases burning material fell onto the copper plate and created a higher temperature reading, which translates into an overestimation of the thermal impact in some cases. 


\section{MEASURES TO PREVENT AND REDUCE CONSEQUENCES}

There is a range of technical measures that can be applied and that are used in Sweden to prevent and mitigate the consequences of arson. Therefore, an inventory of different systems and solutions that are used in Swedish schools was conducted [11]. The inventory was conducted with the help of interviews with representatives from 13 Swedish municipalities along with studies of fire protection documentation of schools buildings. The results form this inventory provide an overview of the typical fire protection systems used to prevent arson in schools and pre-schools.

There is great variety concerning the fire protection systems that are used in the municipalities included in the inventory. Different types of detection systems were most frequently mentioned in the interviews. The most common type of detectors is smoke detectors placed indoors and that are connected to an automatic fire alarm. However, fire detectors in the attic, linear cable detection and thermo sensors were also mentioned as systems to use. Different ways of protecting the building eaves were also extensively applied. None of the interviewed municipalities used any kind of fire suppression system in their schools and preschools. However, sprinkler systems could potentially be used as an alternative to the identified systems and were, therefore, included in the analysis.

This article provides a summary of the most essential and/or common systems presented as: "detection systems", "protection of eaves" and "sprinkler systems". However, other preventative technical measures were also identified in the project, e.g.; the use of lighting in order to increase the visibility around the school at evenings and nights; and the construction of the school so that there are no hidden corners or other secluded areas where potential arsonists can act without being noticed. The full list of technical systems and solutions studied in the project cannot be provided here due to space limitations, but is provided in a separate report [11].

\section{Detection systems}

Five types of detection systems have been analysed in the project: smoke detectors placed indoors connected to an automatic fire alarm; smoke detectors placed in the small non-insulated attics that are common in Swedish school buildings which can detect exterior fires as smoke flows into the attic from the outside through the ventilation openings in the eaves; a linear heat detection cable; differential linear heat detector; and a thermo-sensor that uses thermal imaging for infrared surveillance and can be used to detect suspicious actives around buildings.

Normal closed circuit camera surveillance (CCTV) located near public buildings is problematic due to issues of privacy and it has been difficult to obtain permission to install such cameras in Swedish schools from the Swedish regulatory agencies. Since it is hard to identify individuals with thermo-sensors, the issues of privacy are decreased and it has been possible to obtain necessary permits to install thermosensors around school buildings, which explains their application in Sweden.

Both linear heat detectors and smoke detectors can be connected to an automatic fire alarm system. This can be an existing automatic fire alarm system or a local manual fire alarm system. Thermo-sensors are usually connected to a security company through an Ethernet connection.

These systems act as mitigating systems with one exception. The thermo sensors will detect persons moving around the school even before ignition. This means that actions can be taken to prevent a fire from starting. Such action could be to dispatch security guards or send a message through speakers placed around the school.

\section{Protection of eaves}

Penetration of external fires into the attic through the eaves is very problematic in some one-storey buildings. If the fire spreads into the attic space through the ventilation openings in the eaves it has proven difficult for the fire service to extinguish the fire. The eaves of the building can be protected using several different methods; although this study has been limited to the investigation of two different methods. In the first method the eaves are protected with non-combustible cement-based boards and the ventilation openings in the eaves are closed and replaced with other ventilation solutions in the attic, e.g. small openings under the roof tiles. In the second method, the eaves are protected with incombustible cementbased boards and the ventilation opening on the eave is kept intact but provided with an intumescing 
system that will close the opening in case of fire. This second system is more expensive but can be easily applied in retrofitting an existing building.

\section{Sprinkler system}

Even though the inventory found that very few schools in Sweden are equipped with sprinkler systems it was considered interesting to analyse the potential of such systems in the project. The sprinkler system that was analysed was a conventional sprinkler system that covers most of the spaces inside the school according the current Swedish sprinkler regulations.

\section{Summary of studied measures to prevent and reduce consequences of arson}

The eight different systems studied in detail in the project are categorized in Table 2 in terms of whether they are relevant for the four arson fire scenarios (see Table 1). This categorization provided important input to the evaluation of the efficiency and economics of using the different systems and solutions.

Table 2: Categorization of the eight different systems in regard to the four identified initial fires.

\begin{tabular}{|l|l|l|l|l|}
\hline \multirow{2}{*}{ System } & \multicolumn{4}{|l|}{ Typical initial fire } \\
\cline { 2 - 6 } & $\mathbf{1}$ & $\mathbf{2}$ & $\mathbf{3}$ & $\mathbf{4}$ \\
\hline Conventional fire detector system indoors & & & $\mathrm{X}$ & $\mathrm{X}$ \\
\hline Smoke detector placed in attic & $\mathrm{X}$ & $\mathrm{X}$ & & \\
\hline Linear heat detection cable & $\mathrm{X}$ & $\mathrm{X}$ & & \\
\hline Differential linear heat detector & $\mathrm{X}$ & $\mathrm{X}$ & & \\
\hline Thermo-sensor & $\mathrm{X}$ & $\mathrm{X}$ & $\mathrm{X}$ & $\mathrm{X}$ \\
\hline $\begin{array}{l}\text { Protection of the eaves with incombustible material } \\
\text { and relocation of ventilation opening. }\end{array}$ & $\mathrm{X}$ & $\mathrm{X}$ & & \\
\hline $\begin{array}{l}\text { Protection of the eaves with incombustible material } \\
\text { and intumescing systems in the ventilation opening }\end{array}$ & $\mathrm{X}$ & $\mathrm{X}$ & & \\
\hline Sprinkler system & & & $\mathrm{X}$ & $\mathrm{X}$ \\
\hline
\end{tabular}

The categorization in Table 2 is rough and it has only been done for systems that most likely will act on a certain initial fire e.g. detection indoors may also affect the outcome of fire 1 and 2, but fire spread to the attic can occur without the spread of gases into the building, therefore no categorization has been made for that case.

\section{EVALUATION OF TECHNICAL SYSTEMS}

\section{Experimental work}

The linear heat detection cable and differential linear heat detector have been used in large-scale experiments in order to study the detection time and optimal placement of the detector [12]. Small-scale experiments have also been conducted to study how the linear heat detection cable can be modelled [6]. However, the exterior fire is subjected to the outside environment and the weather conditions will likely have a major impact on the detection time. In order to estimate the benefit of installing different technical systems it is necessary to have an appraisal of the detection time for realistic outdoor scenarios. A detailed description of the experiments can be found in the full report [13]. A brief description of the experimental setup is given here.

\section{Real scale outdoor experiments}

The experiment was performed on the facade of a one-story mock-up building (see Figure 3). Two types of façade cladding were used in the experiments: a non-combustible cement based board and a wooden façade painted with water based paint. The fire source was placed $2.5 \mathrm{~m}$ below the eaves. The eaves were $300 \mathrm{~mm}$ wide and there were ventilation openings into the attic through the eaves. Two sizes of ventilation openings were used: $30 \mathrm{~mm}$ and $60 \mathrm{~mm}$. The distance from the ridge to the floor of the attic was $1.2 \mathrm{~m}$ and the attic was $3.5 \mathrm{~m}$ wide and $6 \mathrm{~m}$ long. All experiments were ignited at the same location on the facade and the wooden façade was replaced between tests. 


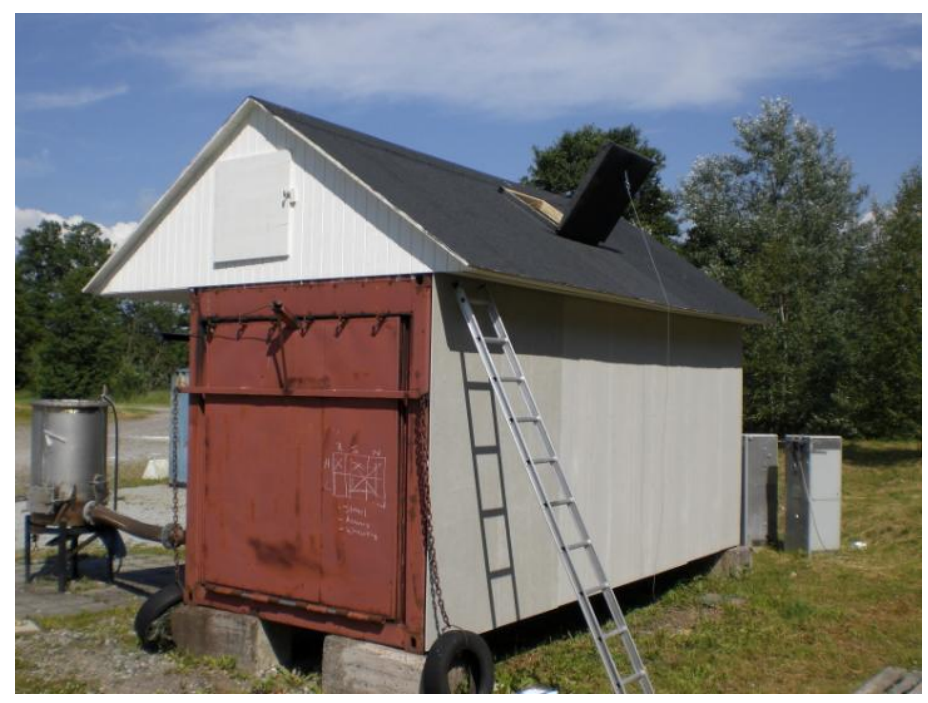

Figure 3: Experimental setup.

Both the linear heat detection cable and the differential linear heat detector were placed on the façade. Smoke detectors were placed in the attic space. Smoke detectors were placed as high as possible in the attic, directly above the fire source and $2.5 \mathrm{~m}$ lateral to the fire source. Temperatures were measured with thermocouples on the facade and in the attic. In two of the experiments a graphite based intumescent system was installed in the eaves in order to prevent the fire to spread into the attic.

Heptane was used as the fuel in all the experiments and four fire sizes were used: 260, 140, 65 and $8 \mathrm{~kW}$. A load cell was used to monitor the mass loss from the fuel. Table 3 summarises the parameters of the various experiments.

Table 3: Description of the different test series.

\begin{tabular}{|l|l|l|l|l|}
\hline Test & $\begin{array}{l}\text { HRR } \\
(\mathbf{k W})\end{array}$ & Facade & $\begin{array}{l}\text { Size of ventilation } \\
\text { opening }(\mathbf{m m})\end{array}$ & $\begin{array}{l}\text { Number } \\
\text { of tests }\end{array}$ \\
\hline 1 & 140 & Incombustible & 30 & 4 \\
\hline 2 & 65 & Incombustible & 30 & 3 \\
\hline 3 & 140 & Combustible & 30 & 2 \\
\hline 4 & 65 & Combustible & 30 & 2 \\
\hline 5 & 140 & Incombustible & 60 & 3 \\
\hline 6 & 65 & Incombustible & 60 & 4 \\
\hline 7 & 8 & Incombustible & 30 & 2 \\
\hline 8 & 260 & Incombustible & 30 & 1 \\
\hline
\end{tabular}

Table 4: Recorded time to detection for the different technical systems.

\begin{tabular}{|c|c|c|c|c|c|}
\hline \multirow[t]{2}{*}{ Technical system } & \multicolumn{3}{|c|}{ Detection time (s) } & \multirow[t]{2}{*}{ Test series } & \multirow{2}{*}{$\begin{array}{l}\begin{array}{l}\text { Number } \\
\text { of tests }\end{array} \\
\end{array}$} \\
\hline & Min & Max & Mean & & \\
\hline Linear heat detection cable & 64 & 400 & 179 & $1,3,4,5,6,8$ & 9 \\
\hline Differential linear heat detector & 16 & 27 & 22 & $3,5,8$ & 4 \\
\hline Smoke detector placed in attic 1 & 88 & 478 & 162 & $1,2,3,4,5,6,7,8$ & 21 \\
\hline Smoke detector placed in attic 2 & 77 & 316 & 168 & $1,2,3,4,5,6,8$ & 18 \\
\hline
\end{tabular}

The detection time varies significantly for the three systems (see Table 4) and it is not possible to see any effect of the facade type or ventilation opening on the detection time. However, there is a trend indicating that a higher heat release rate will provide a faster detection. Detection times for the linear heat detection cable and the differential linear heat detector were consistent with results from previous studies. 
An important issue with regard to efficiency is the reliability of the various detection systems. A sudden increase of temperature is needed for the differential linear heat detector to detect fire and in some of the tests the increase in temperature was too low which resulted in the system not being able to detect the fire. The differential linear heat detector discovered the fire in only 4 of the 21 tests $(19 \%)$, while the linear heat detection cable discovered the fire later but in 9 tests (43\%). The smoke detector closest to the fire (detector 1) discovered all fires and smoke detector farther away discovered all fires except those in test series 7 and test series 2. It must be remembered that the fire size was constant and if the fires had been allowed to grow bigger all detection systems would probably have detected the fire at some point. Based on experimental results (Table 4), the generic detection times in Table 5 were estimated for further evaluation of the systems using cost-benefit analysis.

Table 5: Estimated detection time and detection frequency in the tests.

\begin{tabular}{|l|l|l|}
\hline Technical system & Detection time (s) & Detection frequency \\
\hline Linear heat detection cable & 180 & $43 \%$ \\
\hline Differential linear heat detector & 30 & $19 \%$ \\
\hline Smoke detector placed in attic & 180 & $100 \%$ \\
\hline
\end{tabular}

The thermo-sensor could also be used for the exterior fire (see Table 1) but it was not evaluated in the experiments since these sensors can register heat from people moving around a building and give an alarm before a fire is lit. Therefore, detection time for thermo-sensors was set to 0 seconds.

The graphite based intumescent system placed in the eaves did not expand as intended in the experiments. This was probably due to the fact that the temperatures at the eaves were too low for the intumescent reaction to be initiated. However, the experiment led to a hypothesis that the function of this type of intumescent system should be affected by the heating conditions and that they might not work as expected when heated more slowly than the standard heating curve. Therefore, an additional experimental series was conducted where an intumescent system was tested under a range of different heating and flow conditions in a small-furnace [14].

\section{An intumescent system subjected to different heating conditions}

Standardized methods for classification according to a certain fire rating include rapid heat exposure of the product that is tested, which might not always be the worst case scenario for the product. Previous studies [15] have indicated that the expansion of intumescent systems included in fire seals and fire stoppers are dependent on the heat exposure. A study was therefore initiated to investigate how a graphite based intumescent system, intended for cavities, reacts when subjected to fire conditions different form that in the standardised method EN 1366-4 [16]. Only an overview of the results is given here due to space limitations. A full presentation of the experimental results and analysis is available in a separate publication [16]. Two different experimental setups, a cone calorimeter (ISO 5660) and a small-scale furnace (SP Fire 119), were used in the tests.

Four different heat fluxes were used in the cone calorimeter: 10, 15, 20 and $25 \mathrm{~kW} / \mathrm{m}^{2}$. The temperature on the sample surface was measured using a $0.25 \mathrm{~mm}$ thermocouple (Type $\mathrm{K}$ ) placed in the centre of the sample. Each test lasted for 8 minutes. The sample was video recorded and the time to reaction was estimated visually. The experiment had two purposes; the first was to gain an understanding of how the graphite behaves when subjected to different heating conditions and whether this influences the expansion of the material. The second purpose was to see whether a single critical temperature at which the tested graphite starts to expand could be identified.

In the furnace tests, the intumescent system was placed in a slot $(0.3 \mathrm{~m}$ long and $0.04 \mathrm{~m}$ wide $)$ between blocks of lightweight cellular concrete on top of the furnace in order to give a representation of a vertical cavity in eaves or similar construction. The temperature in the furnace was controlled and kept at different pre-defined heating conditions. Eight different tests were performed and the duration of each test was nominally one hour (see Table 6). 
Table 6: Description of the tests conducted in the furnace experiments [16].

\begin{tabular}{|l|l|}
\hline Test & Description \\
\hline 1 & Standard time temperature fire curve with no cavity vent in place. \\
\hline 2 & Standard time temperature fire curve with cavity vent in place. \\
\hline 3 & Temperature increase of $10^{\circ} \mathrm{C} /$ min during 50 min, then a more rapid increase $\left(40^{\circ} \mathrm{C} / \mathrm{min}\right)$ \\
\hline 4 & $\begin{array}{l}\text { Temperature increase of } 4^{\circ} \mathrm{C} \text { min during } 40 \mathrm{~min} \text {, then a more rapid increase (approximately } \\
\text { according to the standard time temperature fire curve) }\end{array}$ \\
\hline 5 & $\begin{array}{l}\text { Steady temperature of } 150^{\circ} \mathrm{C} \text { during } 40 \text { min, then more rapid increase (approximately } \\
\text { according to the standard time temperature fire curve) }\end{array}$ \\
\hline 6 & $\begin{array}{l}\text { Steady temperature of } 180^{\circ} \mathrm{C} \text { during } 40 \text { min, then more rapid increase (approximately } \\
\text { according to the standard time temperature fire curve) }\end{array}$ \\
\hline 7 & $\begin{array}{l}\text { The cavity vent was placed in water for approximately } 70 \text { hours. The graphite gained } 16 \% \text { in } \\
\text { weight. Then it was subjected to I standard time temperature fire curve in the model furnace. }\end{array}$ \\
\hline 8 & $\begin{array}{l}\text { After } 5 \text { minutes of pre heating with temperature less than the foaming temperature a rapid } \\
\text { temperature and pressure rise was achieved. This test was designed to see if it was possible } \\
\text { to blow away the sealing during the foaming process. }\end{array}$ \\
\hline
\end{tabular}

In the different furnace tests, the intumescent system was subjected to both realistic and extreme heat exposures in contrast to the thermal exposure and pressure specified in tests according to the linear joint seals standard, EN 1366-4 [17]. The experiments showed that the commencement of the expansion reaction in the tested system was approximately $180^{\circ} \mathrm{C}$. The temperature for commencement of the expansion seemed to be rather independent of the incident heat flux, while the expansion rate was clearly dependent on the incident heat flux. Furthermore, the studied system performed well in the small-scale furnace given that the graphite expanded sufficiently to give the same protection as when subjected to a heat exposure similar to the ISO 834 fire curve [18]. This result was independent of whether the system was pre-heated or not and whether the system was wet or dry. An example of the results from the small-scale furnace is presented in Figure 4.

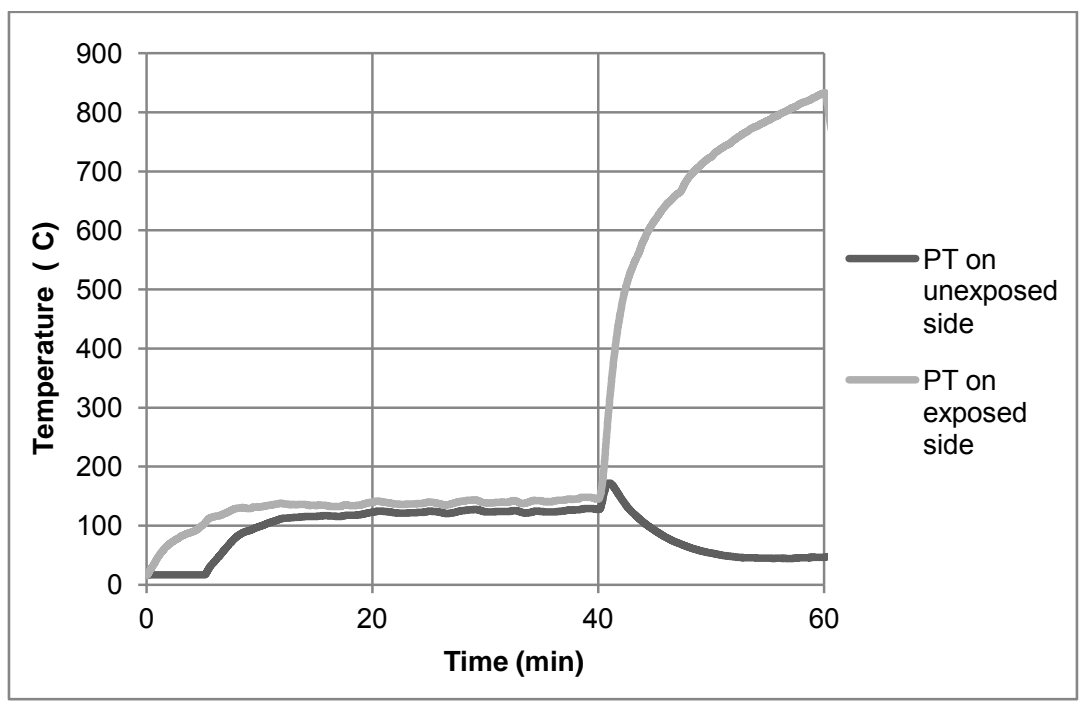

Figure 4: Plate thermometer temperature on exposed and unexposed side of fire stopper in test 6 [16].

Figure 4 illustrates how the temperature in the furnace (grey line) was kept steady at about $180^{\circ} \mathrm{C}$ for 40 minutes at which point the temperature was rapidly increased approximately according to the standard time temperature fire curve. The temperature on the unexposed side (black line) initially follows the temperature in the furnace, but when the temperature increases after 40 minutes the intumescent system expanded and the opening was closed, resulting in a decrease in temperature on the unexposed side. 
While the results from the cone calorimeter and mini-furnaces are positive they are only valid for the system studied and the specific experimental situation. Future research is needed to study how other types of intumescing fire protection systems work when subjected to realistic fire environments.

\section{Sprinkler systems}

No experimental study of sprinkler systems has been conducted in the project since the current knowledge of sprinkler system operations in compartments was considered sufficient for the purposes of the project. A description of how sprinkler systems can be used to mitigate the consequences of arson in school buildings is made in the inventory of technical systems, which is reported separately [11].

\section{Cost-benefit}

In the final part of the project a cost-benefit analysis was conducted [7], [19]. The eight systems presented in Table 2 were studied and two fictive but typical school buildings were used as benchmark cases in the study. Both buildings consisted of a one-storey construction with a non-insulated attic under a gable roof. The first building was a typical pre-school building with a floor area of $1200 \mathrm{~m}^{2}$. No special fire safety measures had been taken to protect the school from loss of property in case of fire. The second building was a school building covering $5000 \mathrm{~m}^{2}$ and equipped with an automatic fire alarm with smoke detectors placed in the school. The initial investment costs (e.g. cost of planning, materials and labour) and future costs (e.g. cost of repairs, service, running and maintenance) were included in the cost-benefit analysis of each system. The net present value method was used to take into account that costs occur at various times during the economic lifetime of the system.

\section{Estimating the costs of the systems}

Information regarding costs of the different systems was retrieved from consultants, manufacturers and contractors. These costs will of course vary between countries, manufacturers and contractors; the costs used in the project must therefore be regarded as rough estimates. Additionally, certain technical systems may have a shorter lifetime than others, but in this analysis the lifetime of all systems has been assumed to be 20 years. The costs for de-commissioning a system have not been considered in this analysis although this could be included if deemed necessary or important.

\section{Estimating the benefit of the systems}

The method of how to estimate the benefit of each system varied between the different types of systems. For the detection systems a value of the money saved per second and the time saved, e.g. the difference between the detection times in the benchmark case and for when a technical system is in place, was used to estimate the benefit. For protection of the eaves and sprinkler system the benefit of taking measures was derived by comparing the estimate expected cost of a fire including measure with the expected cost of the same fire for the benchmark case.

The reliability of each system was accounted for by calculating the expected benefit of the systems. Estimates of the reliability of the different systems were made based on available literature and the previously mentioned experiments.

\section{Cost-benefit ratio}

By dividing the expected benefit with the estimated cost a cost-benefit ratio can be derived. The higher the ratio, the more beneficial is the system. Ratios under 1 are not beneficial. Some of the results from the study are presented in Figure 5. 


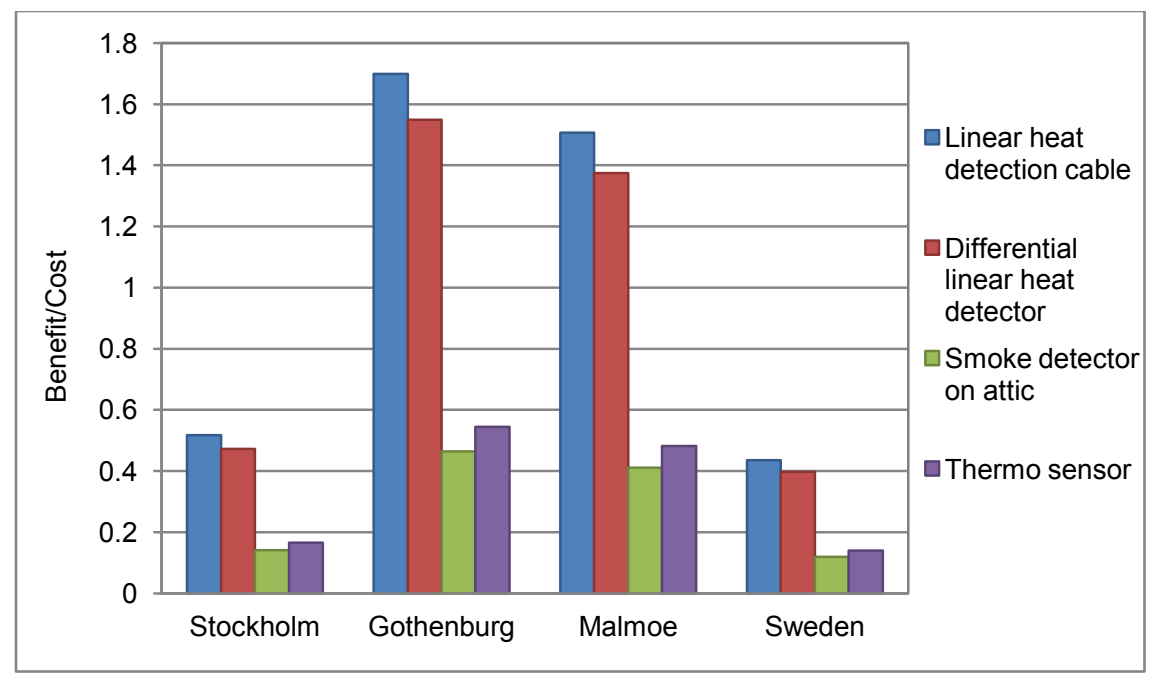

Figure 5: The cost-benefit ratio of the four studied detection systems in the three major cities in Sweden and on a national level.

In Figure 5, the cost-benefit ratios of the four detection systems studied are presented for exterior fires (i.e. fire scenario 1 and 2 in Table 1). In this case the linear heat detectors are superior to the other systems. Even though the differential linear heat detector has been assumed to have a much lower detection time (see Table 5) the difference between the systems is small, this is due to the fact that the linear heat detection cable is less expensive. The results from the entire study are available in a project report [19].

The study showed that some systems have clear cost-benefit advantages for the protection of school buildings in areas where a high fire frequency can be expected, such as Gothenburg and Malmoe but not on a national level. Further it is clear from these results that this method can be used as one basis for determining which system to install. The results are based on the estimation of several key parameters, which means that the results are associated with a high degree of uncertainty. Therefore, a sensitivity analysis has also been performed in the study. It is important to stress that analysis is object specific. General conclusions from the cost-benefit analysis should be treated with care. The method is best suited for application on a case-by-case basis, where the object specific factors are taken into account to evaluate cost-efficient fire safety measures.

\section{DISCUSSION AND CONCLUSIONS}

This paper has provided an overview of key results from a three-year project. The goal and purpose of the project has been to evaluate technical systems and engineering solutions to prevent and reduce the consequences of arson in school buildings. As part of this work have several technical key issues been considered including: identification of typical initial fires, an inventory of available systems and solutions, small and large scale experiments and an extensive cost-benefit analysis. The project is reported in several interim reports [11, 13, 19-21] and in a final report [22].

The results of the cost-benefit analysis are case dependent with several uncertainties imbedded in the costbenefit ratios developed. However, the analysis shows that the technical systems and solutions are profitable in high-risk areas, e.g. areas where fires have occurred recently or where schools have been subjected to other types of vandalism. The cost of systems varies, as does the frequency of arson between different cities and schools; therefore, it is not possible to give a general recommendation on a national level. However, in areas with high arson frequency most systems can be justified. The cost-benefit ratios give ballpark figures and a ranking of the different systems that is considered to be applicable and valuable in the process of deciding which system to install for architects, building designers and other stakeholders.

The experimental work has been essential for the project and it would not have been possible to conduct the cost-benefit analysis with the same precision without the experimental results on detection time of the detection systems and performance of the intumescent system and the detections systems. But there are additional benefits of the experimental work. Firstly, the experimental work on the intumescent system did, among other things, highlight the importance of the behavior of classified products in realistic fire 
environments. This is essential with the regard to performance-based design where analyses of fire protection systems in a building relative to a probable worst-case or realistic fire are important. Secondly, the real scale outdoor experiment provided important experimental data and a clear indication of the significance of weather conditions, especially wind speed and wind direction, as these have a large influence on the experimental results. This possible variability, dependent on weather conditions, is something that designers need to consider when designing for the protection against exterior fires. Finally, the firework experiments represent novel work and constitute important input to future studies of fireworks as ignition sources.

The basis for the entire project is in the identified initial fires. These have been essential both for the inventory, experimental work and cost-benefit analysis. At the start of the project it was considered essential to perform an inventory of possible fires to be used in the future evaluation of the technical systems and solutions. The information generated in the inventory can be valuable for both building designers and in the future research of arson and other kinds of antagonistic actions.

The project is carried out in Sweden and the results are of course primarily applicable for the situation in Sweden but many parts of the projects are relevant in an international context. The description and experimental evaluation of the linear heat detectors and the intumescent system are general and applicable internationally. The same is true for the results from the in-depth study of fireworks as an ignition source. The results from the cost-benefit analysis are strongly linked to the conditions in Sweden but it is believed that the method itself can be applied in a range of different countries where similar types of fire statistics are available.

The large multidisciplinary research program funded by Brandforsk together with a consortium of stakeholders is considered unique in Sweden. The project presented in this paper provides answers to one set of questions, other projects [3,4] give answers to other questions such as the profile of a typical firesetter and other behavioural and social aspects. The success of the efforts in research program will probably only be fully visible in a couple of years, when it has been possible to implement the results of the different projects. However, the work described in this paper has already provided numerous practical and applicable conclusions on a variety of different technical systems and solutions that will help to reduce the consequences of arson in school buildings. Since the start of the research program the number of school arson fires has steadily decreased. It is uncertain whether the focus on this problem caused by the research initiative itself together with other information initiatives are responsible for this decrease. The implementation of findings into school and local government preventative measures, building regulations and societal response will hopefully lead to a continued decrease in the short to long term.

\section{ACKNOWLEDGMENTS}

The research presented in this paper has been conducted within a multidisciplinary project initiated by The Swedish Fire Research Board (Brandforsk) in 2007. This project is financed by The Swedish Civil Contingencies Agency, The City of Malmö, Svenska Kommun Försäkrings AB, Kommunassurans Syd, Länsförsäkringar, Trygg-Hansa, Göta Lejon, St Eriks försäkring, Stockholmsregionens Försäkrings AB, Förenade Småkommuners Försäkringsbolag and KommuneForsikring which are gratefully acknowledged. The Crafoord Foundation, which has financed large parts of this work, is also gratefully acknowledged.

The authors would also like to thank all the co-authors in the different project reports, peer-reviewed papers and conference papers that are a part of this research project.

\section{REFERENCES}

[1] Blomqvist, P. \& Johansson, H., Brandstatistik - Vad vet vi om anlagd brand [Fire Statstics - What do we Know About Arson], report 2008:48, SP Technical Research Institute of Sweden, Borås, Sweden, 2009.

[2] Simonson McNamee, M., Anlagd brand - ett stort samhällsproblem [Arson - A Large Sociatal Problem], report 2007:21, SP Technical Research Institute of Sweden, Borås, Sweden, 2007. 
[3] Lindgren, S-Å, Björk, M., Ekbrand, H., Persson, S. \& Uhnoo, S., Barn/ungdomar som anlägger brand - orsaker och motåtgärder [Juvenile Fire-Setting - Causes and Countermeasures]

Department of Sociology and Work Science, Gothenbrugh Univeristy, 2013.

[4] Guldåker, N., \& Hallin, P-O, Stadens bränder - Del 1 Anlagda bränder och Malmös sociala geografi [The city's fires - Part 1 Arson and Malmö's social geography], Department of Urban Studies, Malmö University, 2013.

[5] van Hees, P \& and Johansson, N., "Use Of Case Studies To Determine Technical Deficiencies With Respect To Fire Spread In School Buildings," 12th International Interflam Conferance, vol. 2. Interscience Communications, Nottingham, England, pp. 1811-1816, 2010.

[6] Johansson, N., Wahlqvist, J. \& van Hees, P., "Detection of a Typical Arson Fire Scenario Comparison Between Experiments and Simulations," Journal of Fire Protection Engineering, vol. 22, no. 1, pp. 23-44, Dec. 2012.

[7] Johansson, N., van Hees, P., Simonson McNamee, M., \& Strömgren, M., "A Cost-Benefit Analysis of Fire Protection Systems Designed to Protect Against Exterior Arson Fires in Schools," in 9th International Conferance on Performance Based Codes and Fire Safety Design Methods, 2012.

[8] Klason, .L-G., Andersson, P., Johansson, N., \& van Hees, P., "Design Fires for Fire Protection Engineering of Swedish School Buildings", in Fire and Materials Conferance, 2011, pp. 159-170.

[9] Hugget, C., "Estimation of Rate of Heat Release by Means of Oxygen Consumption Measurements", Fire and Materials, vol. 4, no. 2, pp. 61-65, 1980.

[10] Klason, L.-G. \& Johansson, N., Fyrverkeripjäser som antändning vid bränder [Fireworks as an Ignition Source in Fires], report 2011:05, SP Technical Research Institute of Sweden, Borås, Sweden, 2011.

[11] Johansson N. \& Klason, L-G., Inventering av tekniska system avsedda att förebygga och begränsa konsekvenser av anlagd brand $i$ skolor och förskolor [Inventory of technical system to prevent and mitigate consequences of arson fires in schools and kindergartens], report 7033, Department of Fire Safety Engineering and System Safety, Lund University, Lund, Sweden,, 2011.

[12] Andersson, P., Persson, H. \& Tuovinen, H.., Råd för installation av värmedetektionskablar på ytterfasad,[Advice for installing heat detection cables on façades], report 2006:09, SP Swedish National Testing and Reserach Institute, Borås, Sweden, 2006.

[13] Johansson, N. \& van Hees, P., Detektering av utvändiga bränder - Resultat från små- och storskaliga experiment [Detection of External Fires - Results from Small- and Real-Scale Experiments], Department of Fire Safety Engineering and System Safety, Lund University, Lund, Sweden,2012.

[14] SP Fire Technology, Fire test of small scale elements of building constructions, SP Fire 119, SP Fire Technology, Borås, Sweden, 2012.

[15] Adl-Zarrabi, B., Influence of temperature, moisture, salt, cleaner compounds and rainwater on the expansion of intumescent fire seal,, report 2007:80, SP Technical Research Institute of Sweden, Borås, Sweden, 2007. 
[16] Johansson, N., van Hees, P., Jansson, R. \& Sjöström, J., "Behaviour of an Intumescing System Subjeted to Different Heating Conditions," Fire and Materials Conferance. San Fransisco, USA, 2013.

[17] European Standards Organisation, Fire resistance tests for service installations - Part 4: Linear joint seals, European Standard EN 1366-4:2006 + A1, 2006.

[18] International Standards Organization, Fire Resistance Tests - Elements of Building Construction Part 1: General Requirements, ISO 834-1, Geneva, Switzerland, 1999.

[19] Johansson, N., Strömgren, M. \& van Hees, P., Anlagd brand Analys av kostnader och nyttor med tekniska system [Arson -An analysis of costs and benefits of technical systems], report 3171, Department of Fire Safety Engineering and System Safety, Lund University, Lund, Sweden, 2013.

[20] van Hees, P., \& Johansson, N., Fallstudier - Vilka tekniska faktorer spelar en roll vid anlagd brand $i$ skolor? [Case studies - Which technical properties play a role with arson fires in schools?], report 3148, Department of Fire Safety Engineering and System Safety, Lund University, Lund, Sweden,2009.

[21] Klason, L-G., Johansson, N. \& P. Andersson, Dimensionerande brand: anlagda skolbränder [Design fires: arson in school buildings], report 2010:15, SP Technical Research Institute of Sweden, Borås, Sweden, 2010.

[22] N. Johansson, P. van Hees, M. S. McNamee, and M. Strömgren, Tekniska system för att förhindra och förebygga anlagd brand - Slutrapport [Technical systems to prevent and mitigate the consequences of arson- Final report], report 3170, Department of Fire Safety Engineering and System Safety, Lund University, Lund, Sweden, 2013. 